\title{
Pengaruh konsumsi musa paradisiaca terhadap produksi ASI pada ibu menyusui
}

\author{
Aprina ${ }^{1}$, Adittio Rinaldi ${ }^{2 *}$ \\ 1Politeknik Kesehatan Tanjung Karang, Bandar Lampung, Email: Aprinamurhan@yahoo.co.id \\ 2Program Studi Keperawatan, Fakultas Kesehatan, Universitas Mitra Indonesia. \\ *Email: aditiorinaldi03@gmail.com
}

\begin{abstract}
The effects of musa $x$ paradisiaca flower by lactating women on breast-milk volume and composition
\end{abstract}

Background: Coverage of breastfeeding in Indonesia reporting by 33 provinces that 29 provinces had (88\%) succeeded in achieving the 2015 as well as strategic plan target. Whereas in 2016 in Indonesia it was found that the percentage of babies getting exclusive breastfeeding up to the age of 6 months was $29.5 \%$ and babies $(0-5$ months) who were breastfed only $54.0 \%$.

Purpose: The effects of musa $x$ paradisiaca flower by lactating women on breast-milk volume and composition in the Working Area of Siring Betik Health Center, Wonosobo-Tanggamus 2019.

Method: A quantitative study by quasi experimental with One group pretest - posttest. The population was 34 respondent, the statistical test used the dependent t-test. The lacation at Siring Betik Health Center, Wonosobo Tanggamus

Results: The results of statistical tests using dependent tests obtained p-values of $0,000(a<0.05)$. There is an influence of Musa x paradisiaca flower by lactating women on breast-milk volume and composition.

Conclusion: This research can be used as a guide to provide counseling about the provision of musa $x$ paradisiaca flower as a non-pharmacological alternative for lactating women. It is inexpesive and finding in tropical country such as Indonesia.

Keywords : Musa x paradisiaca flower; Lactating women; Breast-milk volume; Composition

Pendahuluan: Cakupan pemberian ASI di Indonesia dari 33 provinsi yang melapor, sebanyak 29 di antaranya (88\%) berhasil mencapai target renstra 2015. Sedangkan Pada tahun 2016 di Indonesia diketahui bahwa jumlah persentase bayi mendapat ASI eksklusif sampai usia 6 bulan sebesar $29,5 \%$ dan bayi yang mendapat ASI usia $0-5$ bulan sebesar $54,0 \%$.

Tujuan: Diketahui pengaruh konsumsi Musa Paradisiaca terhadap produksi ASI ibu menyusui di Wilayah Kerja Puskesmas Siring Betik Kec. Wonosobo Kab. Tanggamus Tahun 2019.

Metode: Penelitian Kuantitatif dengan metode Quasi Eksperimental dengan pendekatan One group pretest posttest. Populasi sebanyak 34 responden, sampe yang digunakan adalah ibu menyusui, uji statistik menggunakan uji t-tes dependen. Lokasi di Wilayah Kerja Puskesmas Siring Betik Kec. Wonosobo Kab. Tanggamus

Hasil: Didapat nilai $p$-value $0.000(a<0.05)$. Terdapat pengaruh konsumsi musa paradisiaca terhadap produksi ASI ibu menyusui

Simpulan: Diharapkan penelitian ini dapat dijadikan panduan untuk memberikan penyuluhan tentang pemberian pemberian sayur jantung pisang sebagai alternatif non farmakologi memperlancar ASI kepada ibu menyusui, selain ekonomis dan bahanya mudah didapat

Kata Kunci: Konsumsi musa paradisiaca; Kelancaran ASI; Ibu menyusui.

\section{PENDAHULUAN}

Badan kesehatan World Health Organization (WHO) dan United Nations International Children's Emergency Fund (UNICEF) merekomendasikan: inisiasi menyusu dini dalam waktu 1 jam dari lahir; ASI eksklusif selama 6 bulan pertama kehidupan; dan pengenalan nutrisi yang memadai dan aman komplementer (padat) makanan pada 6 bulan bersama dengan terus menyusui sampai 2 tahun atau lebih. Namun, banyak bayi dan anak-anak tidak menerima makan optimal, dimana hanya sekitar $36 \%$ dari bayi usia 0 sampai 6 bulan di seluruh dunia yang diberikan ASI eksklusif selama 
Pengaruh konsumsi musa paradisiaca terhadap produksi ASI pada ibu menyusui

periode tahun 2007 sampai dengan tahun 2014 (World Health Organization, 2018).

Cakupan pemberian ASI di Indonesia dari 33 provinsi yang melapor, sebanyak 29 di antaranya $(88 \%)$ berhasil mencapai target renstra 2015, sedangkan pada tahun 2016 di Indonesia diketahui bahwa jumlah persentase bayi mendapat ASI eksklusif sampai usia 6 bulan sebesar 29,5\% dan bayi yang mendapat ASI usia 0-5 bulan sebesar $54,0 \%$ (Kementerian Kesehatan Republik Indonesia, 2014).

Tujuan dari pembangunan kesehatan salah satunya adalah menurunkan angka kematian bayi. Angka Kematian Bayi menurut Sustainanble Depelovment Goals (SDGs) tahun 2015 berjumlah 40 per 1000 kelahiran hidup dan masih menempati peringkat ke-4 tertinggi kematian bayi se-ASEAN. Angka kematian bayi (AKB) adalah jumlah kematian bayi dalam usia 28 hari pertama kehidupan per 1.000 kelahiran hidup (Kementerian Kesehatan Republik Indonesia, 2015). Berdasarkan data profil kesehatan Indonesia tahun 2017, bayi yang baru melahirkan mendapatkan inisiasi menyusu dini (IMD) seluruh Indonesia hanya $6,65 \%$, sementara untuk Lampung sendiri hanya $3,03 \%$. Untuk jumlah bayi yang mendapatkan ASI eksklusif sampai dengan enam bulan seluruh Indonesia $35,73 \%$, sedangkan untuk Lampung hanya $32,21 \%$ (Dinas Kesehatan Provinsi Lampung, 2018).

Masalah yang ditimbulkan dari ibu menyusui adalah produksi ASI yang tidak maksimal, sehingga banyak bayi yang kebutuhan nutrisinya kurang karena ibu tidak dapat memberikan ASI maksimal yang sesuai dengan kebutuhan nutrisi bayi. Salah satu penyebab produksi ASI tidak maksimal disebabkan karena asupan nutrisi ibu yang kurang baik, menu makanan yang tidak seimbang, dan juga mengonsumsi makanan yang kurang teratur sehingga produksi ASI tidak mencukupi untuk diberikan pada bayi (Wahyuni, Sumiati, \& Nurliani, 2013).

Menurunnya angka pemberian ASI eksklusif ini disebabkan oleh rendahnya pengetahuan para ibu mengenai manfaat ASI dan cara menyusui yang benar, kurangnya pelayanan konseling laktasi, kurangnya dukungan dari petugas tenaga kesehatan, persepsi sosial budaya yang menentang pemberian $\mathrm{ASI}$, ibu bekerja dan pemasaran susu formula mempengaruhi pemikiran ibu dan para petugas kesehatan (Nainggolan, 2009).
Beberapa sayur yang dapat dijadikan sebagai peningkat kelancaran ASI adalah sayur daun katu, sayur kacang hijau, sayur bayam merah, sayur duan papaya dan juga jantung pisang (Istiqomah, 2014). Indonesia dengan keanekaragaman hayatinya, mempunyai potensi yang sangat besar untuk menyediakan obat alami, mengingat banyak tumbuhan obat yang tumbuh dengan baik. Sejak dulu, bangsa Indonesia telah mengenal tanaman obat dan memanfaatkan untuk menjaga kesehatan dan mengobati penyakit. Pemanfaatan tumbuhan obat tersebut diperoleh berdasarkan pengalaman empirik yang diturunkan dari nenek moyang kita. Pengobatan dengan bahan asal tumbuhan disebut fitoterapi yang dalam penerapannya pada waktu ini dikenal dalam bentuk jamu dan fitofarma (Santoso, 2014; Murtiana, 2011).

Sebagai negara yang terletak di kawasan tropis, di Indonesia banyak ditemukan jantung pisang atau bunga pada pohon pisang. Kandungan nutrisi dalam jantung pisang antara lain protein, karbohidrat, serat, lemak, kalsium , fosfor, zat besi, tembaga, kalium, magnesium, serta vitamin $E$ (Mamuaja, \& Aida, 2014). Pemanfaatan jantung pisang (Musa Paradisiaca) pada masyarakat sudah banyak ditemui, seperti menyembuhkan luka lecet pada kaki, memberikan perasaan kenyang yang lebih lama, digunakan untuk membuat sayur karena kandungan protein dan vitamin, serta dimakan untuk memperlancar dan memperbanyak produksi ASI. Pengolahan jantung pisang pada masyarakat biasa dilakukan dengan cara direbus, diurap, dikukus dan dioseng-oseng. Jantung pisang menjadi bahan makanan yang memiliki banyak manfaat dan mudah didapatkan oleh masyarakat karena bisa dengan mudah ditanam di pekarangan rumah (Wahyuni, Sumiati, \& Nurliani, 2013).

Dengan pemanfaatan jantung pisang batu (Musa Paradisiaca) yang dapat meningkatkan produksi ASI, dapat membantu keberhasilan program pemerintah (Kementerian Kesehatan) dalam upaya pemberian ASI Eksklusif yaitu pemberian ASI saja sampai dengan usia bayi 6 bulan dan tetap diberikan ASI sampai usia anak 2 tahun yang ditambah dengan makanan pendamping ASI (MPASI) (Wahyuni, Sumiati, \& Nurliani, 2013).

Jumlah ASI sedikit bisa diatasi ibu dengan mengkonsumsi jantung pisang, sayur sayuran tersebut terbukti mampu meningkatkan volume air susu ibu. Selain sayur-sayur tersebut, buah-

Aprina', Politeknik Kesehatan Tanjung Karang, Bandar Lampung, Email: Aprinamurhan@yahoo.co.id

Adittio Rinaldi², Program Studi Keperawatan, Fakultas Kesehatan, Universitas Mitra Indonesia.

${ }^{*}$ Email: aditiorinaldi03@gmail.com 
buahan yang mengandung banyak air akan membantu ibu menghasilkan ASI yang berlimpah, seperti melon, semangka, pear, dan banyak lagi buahbuahan berair lain yang sangat baik dikonsumsi ibu menyusui (Katarina, 2014).

Berdasarkan hasil prasurvey yang dilakukan pada tanggal 10 Desember 2018 di Wilayah Kerja Puskesmas Siring Betik, terhadap 10 orang ibu yang memiliki anak usia 4-6 bulan, 7 orang ibu (70\%) menyatakan memberikan susu formula sebagi pelengkap ASI, dikarenakan ibu mengalami penurunan kelancaran ASI, sehingga anak tidak puas, dan tidak cukup jika hanya diberikan ASI saja, selain itu ibu belum pernah mengkonsumsi pelancar ASI seperti ekstrak katuk, daun papaya, atupun konsumsi sayur jantung pisang, sedangkan $3(30 \%)$ diantaranya hanya memberi ASI tanpa bantuan susu formula, atau makanan pendamping lainnya dikarenakan ibu takut jika nutrisi anaknya tidak terpenuhi dan dapat mengganggu pencernaan bayi, selanjutnya kelancaran ASI ibu tidak mengalami gangguan, ibu sering mengkonsumsi sayuran hijau seperti daun katuk, daun papaya dan jantung pisang dibening.

Berdasarka latar belakang di atas maka peneliti tertarik melakukan penelitian dengan judul "Pengaruh konsumsi Musa Paradisiaca terhadap produksi ASI ibu menyusui di Wilayah Kerja Puskesmas Siring Betik Kec. Wonosobo Kab. Tanggamus Tahun 2019"

\section{METODE PENELITIAN}

Jenis penelitian kuantitatif dengan rancangan menggunakan desain Quasi Eksperimental dengan pendekatan one group pretest - posttest design. Populasinya seluruh ibu post partum sebanyak 42 orang yang terdapat di Wilayah Kerja Puskesmas Siring Betik Kec. Wonosobo Kab. Tanggamus. Sampel dalam penelitian ini adalah kelompok 1: 1 sebanyak 34 responden yang dibagi kedalam 2 kelompok perlakuan yaitu 15 kelompok intervensi, dan 15 kelompok kontrol dan pada 1 kelompok perlakuan menggunakan sampel 15-25 responden. Surat keterangan Kelaikan etik Nomor: 215/EA/KEPK_TJK/VIII/2019, didapatkan dari Poltekes Tanjung Karang. Pemberian Musa Paradisiaca yang diberikan kepada responden, melalui enemurator selama 7 hari, sebanyak 200 gr/hari dan dikonsumsi 2 kali sehari. Pada Kelompok intervensi diberikan selama 1 minggu dengan frekuensi 2 kali sehari yang disajikan dalam bentuk sayur kuah bening sebanyak 200 gram. Sementara pada kelompok control hanya diberikan 1 kali sehari saja.

\section{HASIL}

Tabel 1. Produksi ASI Sebelum dan Sesudah Pemberian Musa Paradisiaca

\begin{tabular}{|c|c|c|c|c|}
\hline Variabel & $\mathrm{n}$ & Mean \pm SD & S. Eror & Min- Max \\
\hline $\begin{array}{l}\text { Kelancaran Asi } \\
\text { Sebelum }\end{array}$ & 34 & $4,00 \pm 1,303$ & 0,223 & $2-7$ \\
\hline $\begin{array}{l}\text { Kelancaran Asi } \\
\text { Sesudah }\end{array}$ & 15 & $13,0 \pm 1.00$ & 0,186 & $5-8$ \\
\hline
\end{tabular}

Dari tabel 1 diatas dapat diketahui bahwa produksi ASI ibu menyusui sebelum pemberian musa paradisiaca pada 34 ibu menyusui, dengan mean 4,00 standar deviasi 1,303 standar eror 0,223 dan nilai min-max 2-7. Kelancaran Asi Sesudah pemberian musa paradisiaca pada 15 ibu menyusui, dengan mean 13,0 standar deviasi 1,00 standar eror 0,186 dan nilai min-max 5-8.

Tabel 2. Pengaruh Konsumsi Musa Paradisiaca

\begin{tabular}{lcccc}
\hline Variabel & $\mathbf{n}$ & Mean \pm SD & S. Eror & $p$-Value \\
\hline Pra Intervensi & 34 & $4,00 \pm 1,303$ & 0,223 & 0.000 \\
Post Intervensi & 34 & $7,09 \pm 1,083$ & 0,186 & \\
\hline
\end{tabular}

Aprina', Politeknik Kesehatan Tanjung Karang, Bandar Lampung, Email: Aprinamurhan@yahoo.co.id Adittio Rinaldi ${ }^{2}$, Program Studi Keperawatan, Fakultas Kesehatan, Universitas Mitra Indonesia.

${ }^{*}$ Email: aditiorinaldi03@gmail.com 
Dari tabel 2 terlihat bahwa perbedaan hasil pengukuran terhadap 34 responden untuk melihat kelancaran ASI sebelum diberi sayur jantung pisang dengan mean 4,00 standar deviasi 1,303 standar eror 0,223 dan setelah diberi sayur jantung pisang dengan mean 7,09 standar deviasi 1,083 standar eror 0,186 . Hasil uji statistik menggunakan tes-dependen didapat nilai $p$-value $0.000(a<0.05)$ yang artinya terdapat pengaruh konsumsi musa paradisiaca terhadap produksi ASI ibu menyusui.

\section{PEMBAHASAN}

\section{Produksi ASI Sebelum Pemberian Musa Paradisiaca}

Dari tabel 1 diatas dapat diketahui bahwa produksi ASI ibu menyusui sebelum pemberian musa paradisiaca terhadap 34 orang ibu menyusui, dengan mean 4,00 standar deviasi 1,303 standar eror 0,223 dan nilai min-max 2-7. Penelitian ini sejalan dengan penelitian yang dilakukan pada ibu menyusui di desa Wonokerto Wilayah Puskesmas Peterongan Jombang dan di wilayah puskesmas Sri Kuncoro Kabupaten Bengkulu Tengah. di dapat bahwa produksi ASI sebelum konsumsi sayur jantung pisang rata-rata frekuensi menyusui adalah 5.7 kali dengan standar deviasi 0.80131 dan setelah mengkonsumsi sayur jantung pisang ratarata frekuensi menyusui mengalami peningkatan menjadi 9.75 kali dengan standar deviasi 0.78640 . Kolerasi antara dua variabel adalah sebesar 0.793 dan perbedaan nilai rata-rata peningkatan produksi ASI pada ibu yang tidak mengkonsumsi dan yang mengkonsumsi sayur jantung pisang adalah 4.05000 dengan sig 0.000 . karena sig $<0.05$. maka berarti bahwa rata- rata produksi ASI sebelum dan sesudah konsumsi jantung pisang batu adalah berbeda. Dengan demikian dapat dinyatakan bahwa pemberian jantung pisang batu dapat memperngaruhi peningkatan produksi ASI (Wahyuni, Sumiati, \& Nurliani, 2013; Istiqomah, Wulanadari, \& Azizah, 2015).

ASI adalah makanan yang terbaik bagi bayi pada 6 bulan pertama kehidupannya. Semua kebutuhan nutrisi yaitu protein, kabohidrat, lemak , vitamin, dan mineral sudah tercukupi dari ASI. ASI awal mengandung zat kekebalan tubuh dari ibu yang dapat melindungi bayi dari penyakit penyebab kematian bayi diseluruh dunia seperti diare, ISPA dan radang paru-paru. Dimasa dewasa terbukti bahwa bayi yang diberi ASI memiliki resiko lebih rendah terkena penyakit degenerative, seperti darah tinggi, diabetes type 2, dan obesitas. Sehingga WHO sejak 2001 merekomendasikan agar bayi mendapat ASI eksklusif sampai umur 6 bulan (Fikawati, Syafiq, \& Karima, 2019).

Keberhasilan ibu menyusui sangat ditentukan oleh pola makan, baik di masa hamil maupun setelah melahirkan. Agar ASI ibu terjamin kualitas maupun kuantitasnya, makanan bergizi tinggi dan seimbang perlu dikonsumsi setiap harinya. Artinya, ibu harus menambah konsumsi karbohidrat, lemak, vitamin, mineral dan air dalam jumlah yang sesuai dengan kebutuhan tubuh selama menyusui. Bila kebutuhan ini tidak terpenuhi, selain mutu ASI dan kesehatan ibu terganggu, juga akan mempengaruhi jangka waktu ibu dalam memproduksi ASI (Fikawati, Syafiq, \& Karima, 2019).

Menurut peneliti, produksi ASI merupakan tahap keberhasilan ibu memberikan nutrisi kepada anaknya, bila ibu mengalami kekurangan gizi dan asupan nutrisi maka dapat menyebabkan ASI tidak lancar, sehingga ibu dikatakan tidak berhasil dalam memberikan nutrisi yang cukup kepada bayi tersebut, dalam penelitian ini didapat rata-rata kelancaran ASI dari 17 responden sebesar 4,12 yang artinya ASI keseluruhan responden belum dapat dikatakan lancar.

\section{Produksi ASI Setelah Pemberian Musa Paradisiaca}

Dari tabel 2 diatas dapat diketahui bahwa produksi ASI ibu menyusui sebelum pemberian musa paradisiaca terhadap 34 orang ibu menyusui, dengan mean 7,09 standar deviasi 1,083 standar eror 0,186 dan nilai min-max 5-8.

Jantung pisang merupakan jenis tanaman yang mengandung laktagogum memiliki potensi dalam menstimulasi hormon oksitosin dan prolaktin seperti alkaloid, polifenol, steroid, flavonoid dan substansi lainnya paling efektif dalam meningkatkan dan memperlancar produksi ASI. Laktagogum merupakan obat yang dapat meningkatkan atau memperlancar pengeluaran air susu. Laktagogum sintetis tidak banyak dikenal dan relatif mahal. Hal ini menyebabkan perlu dicarinya obat laktagogum alternatif. Upaya dalam peningkatan produksi ASI bisa dilakukan dengan cara melakukan perawatan payudara sejak dini dan rutin, memperbaiki teknik menyusui, atau dengan mengkonsumsi makanan yang dapat

Aprina', Politeknik Kesehatan Tanjung Karang, Bandar Lampung, Email: Aprinamurhan@yahoo.co.id Adittio Rinaldi², Program Studi Keperawatan, Fakultas Kesehatan, Universitas Mitra Indonesia.

${ }^{*}$ Email: aditiorinaldi03@gmail.com 
Pengaruh konsumsi musa paradisiaca terhadap produksi ASI pada ibu menyusui

mempengaruhi produksi ASI (Harismayanti, Febriyona, \& Tuna, 2019).

Menurut peneliti, Untuk memperlancar produksi ASI sejumlah usaha bisa dilakukan yaitu dengan mengkonsumsi sejumlah booster ASI seperti herbal (daun katuk, daun kelor, jantung pisang dan lainnya) Jantung pisang dipilih karena merupakan jenis tanaman yang mengandung laktagogum memiliki potensi dalam menstimulasi hormon oksitosin dan prolaktin seperti alkaloid, polifenol, steroid, flavonoid dan substansi lainnya paling efektif dalam meningkatkan dan memperlancar produksi ASI. Reflek prolaktin secara hormonal untuk memproduksi ASI, sewaktu bayi menghisap putting payudara ibu, maka akan terjadi rangsangan neurohormonal pada putting susu dan areola ibu. Rangsangan ini akan diteruskan ke hipofisis melalui nervos vagus, kemudian ke lobus anterio. Dari lobus ini akan mengeluarkan hormon prolaktin dan masuk ke peredaran darah dan sampai pada kelenjar-kelenjar pembuat ASI.

\section{Pengaruh Konsumsi Musa Paradisiaca Terhadap Produksi ASI}

Dari tabel 2 terlihat bahwa perbedaan hasil pengukuran terhadap 34 responden untuk melihat kelancaran ASI sebelum diberi sayur jantung pisang dengan mean 4,00 standar deviasi 1,303 standar eror 0,223 dan setelah diberi sayur jantung pisang dengan mean 7,09 standar deviasi 1,083 standar eror 0,186 . Hasil uji statistik menggunakan tes-dependen didapat nilai $p$-value $0.000(a<0.05)$ yang artinya terdapat pengaruh konsumsi musa paradisiaca terhadap produksi ASI ibu menyusui.

Selain itu penelitian ini hasilnya sesuai seperti di wilayah kerja Puskesmas Tambang tahun 2016 dengan hasil penelitian dari 20 responden diperoleh bahwa rata - rata ekskresi ASI sebelum konsumsi rebusan jantung pisang adalah $406 \mathrm{cc}$ dengan standar deviasi 362,43 dan rata - rata ekskresi ASI sesudah konsumsi rebusan jantung pisang adalah $743 \mathrm{cc}$ dengan standar deviasi 82,086 . Hasil uji statistik didapatkan nilai $p$ value 0,001 , maka dapat disimpulkan ada pengaruh konsumsi rebusan jantung pisang terhadap ekskresi ASI pada ibu menyusui (Apriza, 2017).

Penelitian Sebelumnya dengan hasil penelitiannya Dapat diinterpretasikan bahwa hampir seluruhnya dari responden 12 ( 80,0 \%) ibu nifas sesudah mengkonsumsi jantung pisang pengeluaran ASI nya menjadi lancar. Jika hampir seluruh responden sesudah pemberian jantung pisang produksi ASI nya termasuk lancar, maka hal ini disebabkan dengan mengonsumsi jantung pisang maka ibu mendapatkan laktogogum yaitu suatu zat gizi yang dapat meningkatkan dan dapat memperlancar produksi ASI terutama pada ibu yang mengalami masalah dalam produksi ASI (Tjahjani, 2014).

Hasil penelitian ini juga sesuai dengan penelitian sebelumnya yang menunjukan intensitas rata-rata frekuensi ASI sebelum konsumsi jantung pisang 45 adalah 5,7 kali dan setelah konsumsi jantung pisang mengalami peningkatan 9,75 kali. Selain itu menurut penelitian yang dilakukan di Karang penang Kabupaten Sampang, hasil analisa statistik menggunakan Uji paired T-test diperoleh $p$ value sebesar $0,002<$ dari $(0,05)$ sehingga $\mathrm{Ho}$ ditolak dan $\mathrm{H} 1$ diterima yang berarti ada perbedaan produksi ASI sesudah mengkonsumsi jantung pisang. Sesudah diberikan intervensi dapat diketahui bahwa produksi ASI ibu nifas lancar. Hampir seluruhnya produksi ASI ibu nifas lancar yaitu sebanyak 8 orang ibu nifas ( $80 \%$ ) 2 orang ibu nifas produksi ASI tidak lancar (kurang) (Noviana, 2019).

Sesuai teori bahwa nutrisi merupakan makanan yang dikonsumsi dan mengandung zat-zat gizi tertentu untuk pertumbuhan dan menghasilkan energy. Masa nifas memerlukan nutrisi untuk mengganti cairan yang hilang, keringat berlebihan selama proses persalinan, mengganti sel-sel yang keluar pada proses melahirkan, menjaga kesehatan ibu nifas atau memeperbaiki kondisi fisik setelah melahirkan (pemulihan kesehatan), membantu proses penyembuhan serta membantu serta membantu produksi air susu ibu (ASI) (Astutik, 2015).

Jantung pisang yang mengandung laktagogum memiliki potensi dalam menstimulasi hormon okstikosin dan prolaktin seperti alakaloid, polifenol, steroid, flavonoid, dan substansi lainnya paling efektif dalam meningkatkan dan memperlancar produksi ASI. Reflek prolaktin secara hormonal untuk memproduksi ASI, waktu bayi menghisap puting payudara ibu, terjadi rangsangan neorohormonal pada puting susu dan areola ibu. Rangsangan ini diteruskan ke hipofisis melalui nervus vagus, kemudian ke lobus anterior. Dari lobus ini akan mengeluarkan hormon prolaktin, masuk ke peredaran darah dan sampai pada kelenjar-kelenjar pembuat ASI, kelenjar ini

Aprina', Politeknik Kesehatan Tanjung Karang, Bandar Lampung, Email: Aprinamurhan@yahoo.co.id Adittio Rinaldi², Program Studi Keperawatan, Fakultas Kesehatan, Universitas Mitra Indonesia.

${ }^{*}$ Email: aditiorinaldi03@gmail.com 
Pengaruh konsumsi musa paradisiaca terhadap produksi ASI pada ibu menyusui

terangsang untuk menghasilkan ASI (Widiyanto, 2012).

Jantung pisang yang berkhasiat terhadap peningkatan sekresi air susu (laktogogum) mempunyai kandung bahan aktif yang bekerja seperti Prolactin Releasing Hormon (PRH), mengandung bahan aktif senyawa steroid, mengandung bahan aktif yang berkhasiat seperti prolaktin dan mengandung bahan aktif yang berkhasiat seperti oksitosin. Reflek prolaktin secara hormonal untuk memproduksi ASI, waktu bayi menghisap puting payudara ibu, terjadi rangsangan neorohormonal pada puting susu dan areola ibu.Rangsangan ini diteruskan ke hipofisis melalui nervosvagus, kemudian ke lobus anterior. Dari lobus ini akan mengeluarkan hormon prolaktin, masuk ke peredaran darah dan sampai pada kelenjar-kelenjar pembuat ASI (Abadiyah, 2009).

Gizi Seimbang (Balanced Diet) telah dinyatakan oleh berbagai institusi atau kelompok ahli, tetapi pada intinya definisi Gizi Seimbang mengandung komponen-komponen yang lebih kurang sama, yaitu: cukup secara kuantitas, cukup secara kualitas, mengandung berbagai zat gizi (energi, protein, vitamin dan mineral) yang diperlukan tub uh untuk tumbuh (pada anak-anak), untuk menjaga kesehatan dan untuk melakukan aktivitas dan fungsi kehidupan sehari-hari (bagi semua kelompok umur dan fisiologis), serta menyimpan zat gizi untuk mencukupi kebutuhan tubuh saat konsumsi makanan tidak mengandung zat gizi yang dibutuhkan (Kementerian Kesehatan Republik Indonesia, 2014).

Menurut peneliti, produksi ASI dapat dipengaruhi oleh beberapa hal, seperti frekuensi memberikan ASI, makanan yang dikonsumsi hingga pola istirahat, senyawa laktogagum pada sayur papaya dapat meningkatkan kelancaran ASI ibu, hal tersebut dapat dilihat dari peningkatan rata-rata sebelum dan sesudah diberikan sayur jantung pisang, yaitu 4,12 menjadi 6,94 yang artinya terjadi perubahan secara signifikan.

Pada penelitian ini terjadi kenaikan yang signifikan dari produksi ASI ssebelum dan ASI sesudah, peningkatan antara 2-4 poin pada hasil sebelum dilakukan intervensi, menurut peneliti kandungan senyawa laktagogum yang terdapat pada jantung pisang memiliki potensi dalam menstimulasi hormon oksitosin dan prolaktin seperti alkaloid, polifenol, steroid, flavonoid dan substansi lainnya paling efektif dalam meningkatkan dan memperlancar produksi ASI.

\section{SIMPULAN}

Hasil uji statistik menggunakan tes-dependen didapat nilai $p$-value $0.000(\alpha<0.05)$ yang artinya terdapat pengaruh konsumsi musa paradisiaca terhadap produksi ASI ibu menyusui.

\section{SARAN}

Bagi lbu

Diharapkan untuk ibu menyusui agar dapat memanfaatkan sayur jantung pisang sebagai alternatif non farmakologi untuk memperlancar produksi ASI, selain dapat mudah dijumpai dan harganyanya ekonomis, manfaat jantung pisang dapat meningkatkan ASI secara signifikan.

\section{Puskesmas Siring Betik}

Diharapkan penelitian ini dapat dijadikan panduan untuk memberikan penyuluhan tentang pemanfaat sayur jantung pisang untuk meningkatkan produksi ASI pada ibu menyusui.

\section{Bagi Peneliti Selanjutnya}

Diharapkan bagi peneliti selanjutnya agar dapat dijadikan acuan dan sebagai refrensi tambahan terkait penelitian dengan tema alternativ non farmakologi untuk melancarkan produksi ASI bagi ibu menyusui. Diharapkan juga kepada peneliti selanjutnya untuk menggunakan 2 kelompok untuk membandingkan produksi ASI pada kelompok yang diberi sayur dan tidak diberi sayur jantung pisang.

\section{DAFTAR PUSTAKA}

Abadiyah, S. I. (2009). Pemanfaatan jantung pisang kepok (Musa paradisiaca) dengan konsentrasi yang berbeda terhadap mutu dendeng ikan mas (Cyprinus carpio).

Apriza, A. (2017). Pengaruh konsumsi rebusan jantung pisang terhadap ekskresi asi pada ibu menyusui di desa Kuapan wilayah kerja puskesmas Tambang tahun 2016. Jurnal Ners, 1(1).

Astutik, R. Y. (2015). Asuhan Kebidanan Masa Nifas dan Menyusui. Jakarta Trans Info Media.

Aprina', Politeknik Kesehatan Tanjung Karang, Bandar Lampung, Email: Aprinamurhan@yahoo.co.id

Adittio Rinaldi ${ }^{2}$, Program Studi Keperawatan, Fakultas Kesehatan, Universitas Mitra Indonesia.

*Email: aditiorinaldi03@gmail.com 
Dinas Kesehatan Provinsi Lampung. (2018). Cakupan pemberian asi ekskluisif. Data Dinas Kesehatan Provinsi Lampung

Fikawati, S., Syafiq, A., \& Karima, K. (2019). Gizi ibu dan bayi.

Harismayanti, H., Febriyona, R., \& Tuna, M. (2019). Pengaruh konsumsi jantung pisang terhadap peningkatan produksi asi pada ibu masa nifas. In prosiding seminar nasional 2018 "peran dan tanggung jawab tenaga kesehatan dalam mendukung program kesehatan nasional" (pp. 225-234).

Istiqomah, S. (2014). Menanam hidroponik. Ganeca exact.

Istiqomah, S. B. T., Wulanadari, D. T., \& Azizah, N. (2015). Pengaruh buah pepaya terhadap kelancaran produksi ASI pada ibu menyusui di desa Wonokerto wilayah puskesmas Peterongan Jombang tahun 2014. Eduhealth, 5(2).

Katarina, S. (2014). Sehat dengan herbal warisan nenek moyang penumpas segala penyakit. Penerbit; Media IImu Abadi

Kementerian Kesehatan Republik Indonesia. (2014). Panduan gizi seimbang. Jakarta. Kemenkes RI. Diakses dari: https://www.academia.edu/25314413/Pedoman _Gizi_Seimbang_oleh_kemenkes

Kementerian Kesehatan Republik Indonesia.(2014). Pusat data dan informasi Kementerian Kesehatan Republik Indonesia. Diakses dari: https://www.kemkes.go.id/resources/download/ pusdatin/infodatin/infodatin-asi.pdf

Kementerian Kesehatan Republik Indonesia. (2015). Profil Kesehatan Indonesia. Diakses dari:

https://www.kemkes.go.id/resources/download/ pusdatin/profil-kesehatan-indonesia/profilkesehatan-Indonesia-2015.pdf
Mamuaja, C. F., \& Aida, Y. (2014). Karakteristik gizi abon jantung pisang (musa paradisiaca) dengan penambahan ikan layang (Decapterus sp).[Nutritional Characteristics Abon of Banana Inflorescence (Musa Paradisiaca) With Addition Of Scad Fish (Decapterus sp)]. Jurnal IImu dan Teknologi Pangan, 2(2), 28.

Murtiana, T. (2011). Pengaruh konsumsi daun katuk dengan peningkatan produksi asi pada ibu menyusui di wilayah puskesmas Sawah Lebar Kota Bengkulu tahun 2011. Jurusan Kebidanan, Politeknik Kesehatan Bengkulu, Bengkulu.

Nainggolan, M. (2009). Pengetahuan ibu primigravida mengenai faktor-faktor yang mempengaruhi kualitas dan kuantitas ASI di puskesmas Simalingkar Medan.

Noviana, U. (2019). Pengaruh konsumsi jantung pisang terhadap produksi asi pada ibu nifas. Jurnal IImiah Obsgin: Jurnal IImiah IImu Kebidanan \& Kandungan P-ISSN: 1979-3340 e-ISSN: 2685-7987, 11(1), 10-18.

Santoso, U. (2014). Katuk, tumbuhan multi khasiat. Bengkulu: Badan Penerbit Fakultas Pertanian Unib.

Tjahjani, E. (2014). Pengaruh konsumsi jantung pisang terhadap kelancaran asi pada ibu nifas. Grya Husada,(110), 41-46.

Wahyuni, E., Sumiati, S., \& Nurliani, N. (2013). Pengaruh konsumsi jantung pisang batu terhadap peningkatan produksi ASI di wilayah puskesmas Srikuncoro, Kecamatan Pondok Kelapa, Bengkulu Tengah Tahun 2012. Buletin Penelitian Sistem Kesehatan, 15(4 Okt).

Widiyanto, S. (2012). Hubungan pendidikan dan pengetahuan ibu tentang ASI eksklusif dengan sikap terhadap pemberian ASI eksklusif (Doctoral dissertation, UNIMUS).

World Health Organization. (2018). 3 in 5 babies are not breastfed in the first hour of life. Diakses dari https://www.who.int/vietnam/news/detail/31-072018-3-in-5-babies-not-breastfed-in-the-firsthour-of-life

Aprina', Politeknik Kesehatan Tanjung Karang, Bandar Lampung, Email: Aprinamurhan@yahoo.co.id Adittio Rinaldi ${ }^{2}$, Program Studi Keperawatan, Fakultas Kesehatan, Universitas Mitra Indonesia.

*Email: aditiorinaldi03@gmail.com 